\title{
RUNX1/SH3D19 Fusion Gene
}

National Cancer Institute

\section{Source}

National Cancer Institute. RUNX1/SH3D19 Fusion Gene. NCI Thesaurus. Code C99301.

A fusion gene that results from a chromosomal translocation $\mathrm{t}(4 ; 21)(\mathrm{q} 31.1 ; \mathrm{q} 22)$ which fuses exon 5 or 6 of the RUNX1 gene to exon 2 of the SH3D19 gene. This rearrangement is associated with one case of acute myeloid leukemia. 